\title{
OBLICZA STEROWANIA. O PERSWAZJI NIEWERBALNEJ W SZTUCE I REKLAMIE
}

EWA SZCZĘSNA

Zagadnienie perswazji w sztuce, ale też perswadowania sztuką, jest niewątpliwie kłopotliwe. Inspiruje bowiem do postawienia pytania o to, czy perswazja w utworach artystycznych jest ontycznie możliwa, czy może być zasadą organizującą sztukę? Sztuka definiowana jest jako dziedzina ludzkiej aktywności ukierunkowana na realizację celu estetycznego. Oznaczałoby to, że utwory, w których dominantą nie jest estetyka, które realizują przede wszystkim inne cele niż estetyczny (może to być cel perswazyjny, ale też informacyjny, edukacyjny), nie są dziełami sztuki. Tak ogólnie sformułowane twierdzenie eliminowałoby z kręgu sztuki wiele dzieł uznawanych dziś za arcydzieła. W dziejach sztuki często bowiem bywało tak, że pełniła ona funkcję służebną, perswazyjną, a nawet powoływana była do życia w tym celu, zwłaszcza tam, gdzie miała swoich mecenasów (sponsorów). W tej sytuacji ważne jest oddzielenie tego, co inspirowało powstanie utworu, od jego cech immanentnych - formy artystycznej otwartej na różne interpretacje, zdolnej do inicjowania w odbiorcy przeżycia estetycznego. Rozbieżność celów wynikających z intencji mecenasa i formy utworu w ocenie przekazu artystycznego rozstrzygana jest z czasem na korzyść sztuki. Bywało zatem tak, że u podstaw powstania utworu leżały: potrzeba rozsławiania imienia i zasług mecenasa, realizowanie określonych celów społecznych, politycznych, kulturowych, wyrażanych niekiedy w różnego typu manifestach, zaś wraz z biegiem czasu cel ten zanikał, a dzieło broniło się oryginalnością, estetyczną niepowtarzalnością. Bywało jednak i tak, że w sytuacji, gdy tej oryginalności nie było, wraz ze zniknięciem celu, któremu utwór miał służyć, również on sam znikał z pamięci kultury. 
Osobnym zagadnieniem jest późniejsze użycie utworu - mianowicie utwór estetyczny może być używany do innych celów, niż wynikało to z intencji leżących u podstaw jego powstania czy z celów wynikających z jego formy. Takie użycie, wykraczające poza dyskurs estetyczny, oznacza osadzenie utworu artystycznego w innym dyskursie. Może to być na przykład dyskurs polityczny, reklamowy, edukacyjny czy ludyczny. Przykładu dostarczają tu użycia (i nadużycia) dzieł artystycznych czy stylów sztuki do celów propagandowych (np. do budowania wizerunków partii politycznych), perswazyjnych (np. wykorzystywanie w reklamie cytatów i parafraz dzieł sztuki w celu nobilitacji produktów konsumpcyjnych), poznawczych lub w celu kształtowania kompetencji analityczno-interpretacyjnych (cytaty dzieł sztuki w podręcznikach szkolnych). Skala oceny takich użyć jest rozległa - od zdecydowanie negatywnej (w przypadku potraktowania sztuki jako narzędzia manipulacji) do bardzo pozytywnej (zwłaszcza w przypadku pogłębiania wiedzy czy kształcenia umiejętności interpretacyjnych). Jednak każde takie osadzenie utworu artystycznego poza dyskursem sztuki, służące realizacji innego celu niż estetyczny, jest działaniem lokowanym poza istotą sztuki, przekierowuje bowiem cel estetyczny na inny lub podporządkowuje go jemu. W takim ujęciu perswazyjne jest też użycie sztuki w dyskursie naukowym.

Pozaestetyczne użycie sztuki ilustruje przypadek przedstawiającego malarstwa olejnego. Według Johna Bergera malarstwo olejne dostarczało widoku tego, co można było posiąść, a więc widoku przedmiotów, kobiet, pozycji społecznej. „Malarstwo olejne dokonało z wyglądami rzeczy tego samego, czego kapitał dokonał ze stosunkami społecznymi. Wszystko zostało zredukowane do jednego: statusu przedmiotu. [...] Rola tych obrazów nie polegała na przeniesieniu widzów-właścicieli w jakiś nowy dla nich obszar doświadczenia, a jedynie na upiększeniu tego doświadczenia [...]”'. Dlatego obrazy te były, według Bergera, puste i powierzchowne, dlatego też w przedstawieniach kobiecej nagości dominowała uległość, która eliminowała ekspresję uczuć. Obraz olejny ubiegłych wieków odpowiadał na potrzebę posiadania, nie zaś na potrzebę doświadczenia estetycznego.

1 J. Berger, Sposoby widzenia, tłum. M. Bryl, Warszawa 2008, s. 87, 101. 
Tymczasem mianem sztuki określane są utwory, których niepowtarzalna forma (styl, kompozycja, niepowtarzalne rozwiązania formalne) staje się w sytuacji odbioru impulsem uruchamiającym doświadczenie estetyczne, rozumiane jako rodzaj przeżycia intelektualno-emocjonalnego. „Doświadczenie estetyczne - pisze Umberto Eco - opiera się na przyjemności, jaka mu towarzyszy, i nie może dyskwalifikować lub wykluczać innych doświadczeń estetycznych"2. Oznacza to, że dyspozycja (zdolność) ta może być zmienna w czasie i przestrzeni. Nie bez znaczenia dla niej będą też kompetencje i gust estetyczny odbiorcy. W przypadku arcydzieła owa zdolność ma charakter uniwersalny - jest ponadczasowa i ponadkulturowa, w mniejszym stopniu też zależy od jednostkowego gustu odbiorcy.

Nie znaczy to, że utwory sztuki wolne są od perswazji. Wręcz przeciwnie. Zdolność do wytwarzania w odbiorcy przeżycia intelektualno-emocjonalnego jest w swej istocie zdolnością perswazyjną. Akt uruchomienia doświadczenia estetycznego przez odbiorcę $\mathrm{w}$ kontakcie ze sztuką jest spełnieniem aktu powodowania. Ważną cechą powodowania jest jednak to, że służy ono realizacji funkcji estetycznej. Bez jego udziału nie byłaby wręcz możliwa realizacja tego doświadczenia. Krótko mówiąc, w akcie przeżycia estetycznego zawarte jest działanie perswazyjne jako konieczny element $\mathrm{i}$ jednocześnie narzędzie umożliwiające uruchomienie doświadczenia estetycznego. W jakiś sposób literatura (i szerzej - sztuka) sprawia, że - jak pisze Paul Hamon $^{3}$ - wierzymy, że naśladuje rzeczywistość. Ta władza powodowania przyczynia się do tego, że odbiorca zawiesza niewiarę, angażując się w dyskurs fikcjonalny jak w rozmowę o rzeczywistym świecie, mimo świadomości uczestniczenia w grze, która rządzi się własnymi prawami (w której reguły semantyczne są zmienione) $)^{4}$. Zawieszenie niewiary, które sprawia, że angażujemy się w świat fikcjonalny jak w rzeczywisty, jest elementem działania perswazyjnego sztuki. Co więcej, odnosi się ono nie tylko do świata przedstawionego i jego elementów, lecz także do skłonności odbiorcy, czy wręcz

2 U. Eco, Uwagi o ograniczeniach estetyki, tłum. P. Salwa, [w:] idem, Sztuka, Kraków 2008, s. 58.

3 P. Hamon, Ograniczenie dyskursu realistycznego, tłum. Z. Jamrozik, „Pamiętnik Literacki” 1983, z. 1, s. 234.

4 Zob. omówienie tego problemu w: R. Rorty, Konsekwencje pragmatyzmu. Eseje z lat 1972-1980, tłum. Cz. Karkowski, Warszawa 1998, s. 154-183. 
uporu, z jakim opatruje on utwór sztuki sensem. Ustanawianie, przypisywanie i określanie znaczeń, o których odbiorca sztuki ma skłonność myśleć jako o odnalezionych, rozkodowanych, istniejących, to kolejny przejaw władzy powodowania doświadczenia estetycznego. Ko mpetencja pers wa zyj n a sztuki jest władzą, jaką roztacza forma artystyczna, dyspozycją zawartą w języku sztuki i ukierunkowaną na przekonywanie do niej samej.

Doskonałym przykładem tego działania są grafiki Mauritsa Cornelisa Eschera. Forma, jaką dla swych grafik wybiera Escher, pozwala przekonać widza do istnienia przestrzeni niemożliwych. Realistyczną, wyrazistą kreską, konkretnością każdego elementu przedstawienia, namacalnością i jawnością przejść od jednej realności do drugiej Escher uprawdopodabnia to, co dziwne, absurdalne, niewytłumaczalne. W zaproponowanej przez siebie formie artystycznej łączy ze sobą, a nawet uzgadnia światy całkowicie odmienne lub - co ważne - uznawane za takie w efekcie nawyków percepcyjnych, jakie dochodzą do głosu w sytuacji odbioru. Sky and Water I, Puddle, Metamorphosis II, Drawing Hands, Reptiles to przykłady utworów, których tematem jest nie tylko godzenie różnych wymiarów przedstawiania, różnych światów, ale też które uzasadniają tezę o zazębianiu się i współistnieniu tych odmienności, o ich interferencji i wyrastaniu jednej z drugiej. To sztuka, która przekonuje nie tyle o równouprawnieniu różnych perspektyw poznawczych, interpretacji i światów w nich wytwarzanych, ale wręcz o ich tożsamości.

A oto inny przykład. Rzeźby z marmuru Michała Anioła - odlewy z brązu perswadują lekkość formy artystycznej, przekonują do żywotności, często oddają ruch, dynamikę. Podejrzewam, że mało kiedy odbiorca starożytnej Grupy Laokoona, renesansowych rzeźb Michała Anioła czy barokowych rzeźb Gianlorenza Berniniego myśli o ciężarze materii, który forma nie tylko zakrywa, ale wręcz przeciwstawia się mu. Św. Weronika Mochiego, Apollo i Dafne Berniniego konotują ruch, dynamikę, angażują widza w dopowiadanie działań. Realizm, wręcz namacalność przedstawienia ciała ludzkiego w przypadku rzeźb Michała Anioła, by przywołać tu choćby uwidocznienie na powierzchni dłoni Dawida napięcia ścięgien, biegnących pod skórą żył, ewokują życie, ciepło ludzkiego ciała, sprawiają, że odbiorca opatruje je witalnością. Podobnie witalność, lekkość i ruch ewokują rzeźby Antonio Canovy. Nie mniej zwodnicze są kamienne przedstawienia materii okrywających ciało modela - ich pofałdowania, przezroczystości, a nade 
wszystko miękkości. Dopiero dotyk rzeźby demaskuje iluzję, odsłania perswazyjność formy, która przekonuje widza o lekkości, dynamice, cieple, miękkości wielotonowych, zimnych, twardych i nieruchomych kamiennych posągów. Dotyk, który nas zaskakuje, pozwala w pełni przekonać się o sile formy artystycznej, która przeczy materii, odsłaniając perswazyjną moc sztuki rzeźbiarskiej. Dlatego też pewnej rewizji wymaga teza Johna Bergera odnosząca się do dzieł malarstwa olejnego: „Jakkolwiek obrazy te są dwuwymiarowe, iluzjonistyczny potencjał malarstwa olejnego jest o wiele większy niż analogiczny potencjał rzeźby, ponieważ może ono sugerować obiekty posiadające barwę, teksturę i temperaturę, wypełniające przestrzeń, a zatem - przez implikację - cały świat"5.

W zasadniczo odmiennej niż sztuka relacji do perswazji pozostaje reklama. Podczas gdy dyskurs sztuki ukierunkowany jest na realizację funkcji estetycznej, której podporządkowane zostają inne funkcje (jak choćby poznawcza czy perswazyjna), w dyskursie reklamy kluczową rolę pełni funkcja perswazyjna, która modeluje inne funkcje, np. estetyczną czy informacyjną. To sprawia, że perswazja we współczesnej reklamie, postrzeganej w gospodarkach wolnorynkowych jako składnik procesu marketingowego, może być definiowana w kategoriach władzy w rozumieniu Michela Foucault, a więc jako przyjęte, wpisane w model społeczeństwa konsumpcyjnego „[...] strategie, za pomocą których jednostki próbują wpływać na zachowanie innych"6. W tym ujęciu stosunki władzy nie są złem, próbą zawładnięcia drugim, ale grą czy przyjętymi strategiami działań, bez których nie może się obyć żadne społeczeństwo. To gry, które zakładają wolność obu stron. Jak pisze Foucault: „[...] należy odróżniać stosunki władzy jako strategiczne gry między wolnościami - strategiczne gry, w których jedni próbują wpływać na zachowanie innych, na co ci drudzy odpowiadają próbą uniknięcia tego wpływu lub próbą wywarcia własnego wpływu na innych - od stanów dominacji, które są tym, co zwykle nazywamy władzą"7.

5 J. Berger, op. cit., s. 88-89.

${ }^{6}$ M. Foucault, Kim pan jest, profesorze Foucault? Debaty, rozmowy, polemiki, red. B. Błesznowski, K.M. Jaksender, K. Matuszewski, tłum. K.M. Jaksender, Kraków 2013, s. 235.

7 Ibidem, s. 236-237. 
Elementem takiej gry jest posługiwanie się w reklamie perswazją niewerbalną (ikoniczną i dźwiękową), przy czym jej wykorzystanie staje się nie tylko możliwe, ale i coraz bardziej skuteczne wraz z rozwojem mediów - nowoczesnych technik rejestracji, a następnie przetwarzania dźwięku i ruchomego, barwnego obrazu ${ }^{8}$. Coraz bardziej też doceniana jest siła tej perswazji, jej skuteczność - często większa niż perswazji słownej.

Za skutecznością perswazji niewerbalnej przemawiają: szybka, niemal automatyczna percepcja obrazu, bezpośredniość oddziaływania dźwięku na emocje oraz wzmocnienie oddziaływania estetycznego. Medialne reprezentacje dźwięku i obrazu, mimetyczne w stosunku do rzeczywistości otaczającej odbiorcę, mają zdolność łatwego wnikania (a nawet wkradania się) w świat odbiorcy. Rejestrujemy je i interioryzujemy na ogół bardziej automatycznie niż cudze słowo, które jako nie-własne, pochodzące od innego, konkurencyjnego podmiotu, poddajemy często znacznie surowszej kontroli. Przedstawienia ikoniczne i dźwięk odbierane są zwykle najpierw percepcyjno-emocjonalnie, a dopiero później bywają interpretowane intelektualnie. Inaczej jest w przypadku słowa, które na ogół najpierw przetwarzamy percepcyjnie i rozumowo (dekodujemy i interpretujemy), a dopiero później na nie odpowiadamy (przyjmujemy, odrzucamy, zajmujemy stanowisko wobec niego). To prowadzi do wytworzenia dystansu, który dodatkowo rośnie w sytuacji odbioru słowa pisanego (i drukowanego). Tymczasem podczas odbioru przekazów niewerbalnych dystans ten zwykle zanika. Okazuje się, że mamy skłonność do zapominania o tym, że zapośredniczony medialnie obraz i dźwięk w nie mniejszym stopniu niż słowo mogą informować, wartościować, oddziaływać na nas, przekonywać do czegoś, a nawet nami sterować (manipulować).

Perswazję niewerbalną zdefiniować można jako takie użycie znaków ikonicznych, w tym również ruchomego obrazu oraz dźwięku (także muzyki), którego celem jest wywarcie wpływu na podejmowane przez kogoś decyzje, działania czy poglądy. W takim ujęciu przedstawienia obrazowe i dźwiękowe stają się nie tyle argumentami ${ }^{9}$, gdyż jako konstrukcje niewerbalne

8 Zob. E. Szczęsna, Znaki niewerbalne, [w:] eadem, Poetyka reklamy, Warszawa 2001.

9 O argumentach wizualnych zob. J.A. Blair, The Rhetoric of Visual Arguments, [w:] Defining Visual Rhetorics, ed. Ch.A. Hill, M. Helmers, New Jersey 2004. 
nie mogą być sądami sensu stricto, ale reprezentacja mi a rgumentów. Bycie niewerbalną reprezentacją argumentu rozumiane jest tu jako taki sposób organizowania obrazu lub dźwięku, który staje się impulsem dla odbiorcy do mniej lub bardziej eksplicytnego sformułowania argumentu $\mathrm{w}$ akcie odbioru - w procesie referencyjno-interpretacyjnym. I tu pojawia się pierwsza korzyść płynąca z zastosowania perswazji niewerbalnej. Otóż w ujęciu Foucault przypisana obu podmiotom wolność w sposób konieczny musi implikować możliwość dokonania wyboru. O świadomym wyborze, jako tym, co powiązane jest z perswazją, pisze też J. Anthony Blair, według którego możliwość dokonania takiego wyboru jest cechą rozpoznawczą perswazji. Odbiorca staje wobec argumentu, który może przyjąć - i w efekcie podjąć jakieś działanie lub zmienić zdanie o czymś, dotychczasową postawę czy przekonania. Tymczasem niewerbalne reprezentacje argumentów nie formułują sądów, ale wymagają tej aktywności od odbiorcy. Odbiorca najpierw musi sformułować argument, by następnie móc go przyjąć lub odrzucić. Zaangażowanie odbiorcy w samodzielne formułowanie argumentu sprawia, że ten postrzega ów argument jako bardziej własny. Ponieważ zaś mamy większą skłonność do przypisywania waloru prawdy własnym sądom niż cudzym, istnieje też większe prawdopodobieństwo, że zaakceptujemy sformułowany przez siebie sąd, niż że go odrzucimy.

Oto przykład. W audiowizualnej reklamie opon odbiorca widzi czarnoskórą biegaczkę uciekającą przed goniącymi ją żywiołami: wodą (tu również lodem) oraz ogniem. Żywioły poddane zostają animizacji - przybierają nieskonkretyzowaną do końca postać potworów; w przesuwających się ze znaczną prędkością ogniu i wodzie widać zarys ich twarzy. Ubranej w sportowy kostium młodej, pięknie zbudowanej kobiecie (granej przez zawodową biegaczkę) udaje się umknąć przez żywiołami. Odbiorca widzi jej dynamiczny bieg wśród ognia, wody, po niemal pionowych skałach oraz wybicia do skoków, które pozwalają jej zyskać dystans, po czym podejmuje ona dalszy bieg. Na koniec, gdy kobieta staje na szczycie najwyższego wzniesienia i przesuwa palcami dłoni po spodniej części stopy, widz może dostrzec na niej bieżnik opony. Całość wieńczą umieszczone na tle kręcącej się opony nazwa marki oraz napis mówiący o tym, że siła, moc są niewiele warte bez kontroli.

Przywołany spot oparty jest na kilku podstawowych dla reklamy zabiegach, które użyte są w sposób perswazyjny, a których materią są w tym 
przypadku znaki niewerbalne. Są nimi: narratywizacja, metaforyzacja (epitety zaangażowane w myślenie metaforyczne) oraz odwołanie się do odbiorczej znajomości konwencji gatunku. Ruchomy, udźwiękowiony obraz poddany zostaje narratywizacji, której dokonuje odbiorca. Dynamiczny ruch zmieniających się przedstawień, wzmocniony dynamiczną muzyką uzgodnioną rytmicznie z ruchem obiektów i ruchem kamery, sprawia, że odbiorca przekształca je w zdarzenia, które wiąże w relacje przyczynowo-skutkowe, tworząc opowieść.

Perswazyjna wartość narracji zasadza się przede wszystkim na tym, że jest ona strukturą, która angażuje odbiorcę, zaciekawia ${ }^{10}$, sprzyja nawiązaniu z nim kontaktu. Ponadto to, co w niej umieszczone, łatwiej zapisuje się w pamięci i na dłużej w niej pozostaje. Poszczególne powiązane ze sobą elementy opowieści uzasadniają wzajemnie swoje istnienie. W tym przypadku jest to o tyle istotne, że elementami tymi są wyglądy i zdarzenia, które zaświadczają o cechach reklamowanych opon (są ich reprezentacją). Narracja audiowizualna pełni tu funkcję dokumentowania, dostarcza też argumentacji przez przykład. Dodatkowo przemyca ocenę, co Paul Ricoeur uważał za własność każdej narracji ${ }^{11}$. I tak w analizowanym spocie piękno i szybkość biegaczki są reprezentacją atrakcyjności opon i szybkości zaopatrzonego w nie samochodu; bieg kobiety po pionowych powierzchniach oraz skoki zakończone lądowaniem bez przesunięcia stóp choćby o centymetr inicjują myśl o przyczepności reklamowanych opon; ucieczka z przestrzeni ognia, lodu i wody zaświadczają o odporności opon na różne temperatury oraz o tym, że sprawdzają się one w każdych warunkach; warto dodać, że wzmocnienie (emfazę, hiperbolizację) odporności na ekstremalne temperatury uzyskuje się na drodze utrzymania całych ujęć bądź w niebieskim, bądź w czerwono-żółtym kolorze.

Przedstawienia stają się substytutami własności, wręcz samymi cechami, dzięki temu, że przekaz odwołuje się do odbiorczej znajomości gatunku

10 Tomasz Mann w swoich esejach stawia tezę, że „tajemnica narracji [...] polega na tym, żeby to, co właściwie powinno być nudne, uczynić ciekawym”. Zob. T. Mann, Sztuka powieści. Wykład na uniwersytecie w Princeton, tłum. M. Zurowski, [w:] idem, Eseje, wyb. D. Żmij-Zielińska, Warszawa 1998, s. 62.

${ }_{11}$ P. Ricoeur, O sobie samym jako innym, tłum. B. Chełstowski, Warszawa 2003, s. 271. 
reklamy. Gdyby klip filmowy odbierany był przez kogoś, kto nigdy nie miał do czynienia z reklamą, bieg kobiety wśród lodu i ognia raczej nie byłby przez niego interpretowany jako informacja o odporności opony na różne temperatury. To powszechna znajomość gatunku, wszechobecnego we współczesnej kulturze społeczeństwa konsumpcyjnego, jego rozpoznawalność, nabyta w toku obcowania z przekazami obecnymi w przestrzeni wszystkich mediów, sprawiają, że widz uruchamia myślenie metaforyczne przenosi cechy biegaczki na przedmiot reklamy, dokonując jednocześnie modyfikacji w sferze interpretacyjnej tych cech, bo przecież atrakcyjność kobiety wynika z piękna jej wysportowanej sylwetki, zaś atrakcyjność opony z solidności, funkcjonalności przedmiotu reklamy. Tym, co dodatkowo ułatwia uruchomienie myślenia metaforycznego, jest kolor skóry biegaczki, a także bieżnik widoczny w niektórych ujęciach na jej stopach i plecach.

W prezentowanej reklamie ruchomy obraz i dźwięk tworzą reprezentacje kilku argumentów na rzecz przedmiotu reklamy. Zwykle jednak reklama poprzestaje na jednej cesze czy informacji, której werbalizacji (umieszczenia w świadomości językowej) dokonuje odbiorca pod wpływem przedstawienia ikonicznego lub audiowizualnego. Tak jest na przykład w audiowizualnej reklamie piwa, gdzie całe zdarzenie, w swej wymowie humorystycznej, jest reprezentacją tylko jednego argumentu za reklamowaną marką. Tym argumentem jest męskość.

Krótki, bo zaledwie trzydziestosekundowy, film ukazuje w półzbliżeniu młodą, atrakcyjną kobietę, która z wypisanym na twarzy uczuciem błogości zdejmuje szlafrok i wchodzi do dużej, okrągłej wanny, by rozkoszować się kąpielą. Zamglone zdjęcia, utrzymane w zwolnionym rytmie, oraz nastrojowa, transcendentna muzyka oddają stan emocjonalny i subtelną osobowość bohaterki. Ze sceną tą skontrastowane zostaje kolejne ujęcie, w którym do tej samej wanny nagle $\mathrm{z}$ radością i impetem wskakuje młody mężczyzna, rozchlapując na boki wodę. Mężczyzna chwyta za umieszczoną w wiaderku $\mathrm{z}$ lodem butelkę piwa i $\mathrm{z}$ wypisanym na twarzy wyraźnym zadowoleniem wypija jej zawartość. Następnie radośnie spogląda w stronę kobiety, a widząc jej konsternację i nie rozumiejąc jej, ze zdziwieniem pyta, co się stało (o co jej chodzi).

$\mathrm{W}$ audiowizualnej reklamie piwa to, co kobiece (wysublimowanie, estetyka, kontemplacja przyjemnej chwili, subtelność, tajemnica, doświadczenie przyjemności - zbliżenie do szczegółu - dotyk), i to, co męskie 
(prostolinijność, bezpośrednie działanie, przygoda, brak finezji, dziecięca radość, wieczna chłopięcość oraz piwo) zostają pokazane jako kontrastowo różne, ale i uzupełniające się - kobieta i mężczyzna są ze sobą związani emocjonalnie, wiodą wspólne życie, czego znakiem jest wspólna kąpiel w luksusowej wannie - okrągłej, co też przemawia na rzecz symboliki wspólnoty, pojednania, porozumienia.

Odbiorca ma zatem do czynienia z reprezentacją jednego argumentu, za to umieszczonego w scenie silnie oddziałującej na emocje. Zastosowanie humoru opartego na Kantowskiej zasadzie kontrastu tego, co spodziewane, z faktycznym rozwiązaniem - tym, co następuje, a co jest biegunowo odległe od oczekiwań projektowanych przez widza - wzmacnia oddziaływanie perswazyjne. Umiejętne umieszczenie przedmiotu reklamy w scenie finałowej sprawia, że silnie oddziałujące na emocje zdarzenie wspomaga zapamiętanie przedmiotu reklamy i sprzyja powiązaniu z nim pozytywnych emocji. Dodatkowo brak warstwy językowej przenosi obowiązek interpretacyjny przekazu na odbiorcę, wywołując jego zaangażowanie.

W przypadku obu prezentowanych reklam cechy, własności przedmiotu zostają unaocznione - są przykładem, który potwierdza prawdziwość sformułowanych przez widza argumentów. Koło zostaje zamknięte. Najpierw przedstawienie audiowizualne, interpretowane przez odbiorcę jako metaforyczna, niewerbalna reprezentacja argumentów, inspiruje go do sformułowania tez na temat przedmiotu, by następnie tezy te - cechy przedmiotu przemawiające za jego doskonałością: szybkość, przyczepność, bezpieczeństwo, odporność na wszelkie temperatury, atrakcyjność - znalazły unaocznienie, potwierdzenie na prawach argumentu w zaprezentowanym konkretnym przypadku. To, co pokazane - istnieje. Jesteśmy o tym przekonani zwłaszcza w sytuacji obcowania z przedstawieniami realistycznymi o transparentnym dla odbiorcy nacechowaniu stylistycznym ${ }^{12}$, mającymi cechy fotograficznego odwzorowania. Siła naszej skłonności do utożsamiania takich przedstawień $\mathrm{z}$ rzeczywistością ${ }^{13} \mathrm{i}$ do zawieszania niewiary jest tak wielka, że nie znosi jej nawet powszechna wiedza o komputerowym

12 O stylu transparentnym (stylu zerowym) w filmie zob. M. Przylipiak, Kino stylu zerowego. Z zagadnień estetyki filmu fabularnego, Gdańsk 1994.

13 B. Reeves, C. Nass, Media i ludzie, tłum. H. Szczerkowska, Warszawa 2000, s. 15-17. 
przetwarzaniu, a nawet wytwarzaniu obrazów reklamowych - o tym, że możliwe jest zaprogramowanie i pokazanie rzeczy, które w rzeczywistości nie istnieją (przykład fotorealizmu).

Retoryczną, czy wręcz perswazyjną siłę oczywistości obrazu - oczywistości niemal apodyktycznej, gdyż zdolnej do przekonania odbiorcy do czegoś, czego nie da się pomyśleć - dostrzega Michał Rusinek we wspomnianych już grafikach Eschera. Według badacza, Escher w swoich przedstawieniach dowodzi możliwości przedstawienia tego, czego nie da się pomyśleć, dowodzi „Wyższości widzenia nad rozumieniem, a więc i obrazu nad słowem” ${ }^{14}$. W przypadku grafiki Wodospad „To, do czego nas [artysta - przyp. E.Sz.] przekonuje, jest nierealne, nonsensowne, absurdalne i nielogiczne - a jednak próbuje [on to zrobić - przyp. E.Sz.], wierząc w retoryczną siłę swojego obrazu"15.

Siły, jakiej źródłem jest uczynienie czegoś widocznym, dowodzi zresztą już Arystotelesowskie ujęcie retoryki jako sztuki unaoczniania. Wobec werbalnego prezentowania rzeczy tak, że staje się ona widoczna (co charakteryzowało na przykład hypotypozę $\left.{ }^{16}\right)$, przedstawienie ikoniczne - w szczególności fotograficzne - zyskuje na realności, konkretności, zwłaszcza że jego przedmiotem jest to, co znajduje się w otoczeniu odbiorcy. „Efektywność reklamy polega właśnie na tym, że żywi się tym, co realne - pisze John Berger. - Odzież, żywność, samochody, kosmetyki, kąpiele, światło słoneczne - są realnymi rzeczami, które jako takie dostarczyć mogą prawdziwej przyjemności"17.

Obraz w reklamie unaocznia nie tylko konkretne byty, ale i wartości, które odbiorca może mieć, nabywając reklamowane przedmioty. Miłość, piękno, dostatek, zadowolenie, bezpieczeństwo, dobro, a w efekcie szeroko pojmowane szczęście zostają ujęte w konkretnych przedstawieniach obrazowo-dźwiękowych. Ich reprezentacją jest nie tylko zawartość tematyczna

${ }_{14}$ M. Rusinek, Retoryka obrazu. Przyczynek do percepcyjnej teorii figur, Gdańsk 2012, s. 71-72.

15 Ibidem, s. 65.

16 A. Dziadek, Relacja obraz - tekst. Próba charakterystyki typologicznej, [w:] Dwudziestowieczna ikonosfera w literaturach europejskich. Wizualizacja w literaturze, red. B. Tokarz, Katowice 2002, s. 144-145.

17 J. Berger, op. cit., s. 132. 
przekazu - piękni, uśmiechnięci, młodzi bohaterowie, świat sukcesu, którym są otoczeni - ale i jego warstwa semiotyczna.

Ukazywanie świata z przedmiotem reklamy jako doskonałego, charakteryzowanie przedmiotu jako zdolnego do przekształcania zwyczajnej codzienności odbiorcy w przestrzeń szczęścia uzyskuje się często na drodze posłużenia się barwami nasyconymi, jasnymi, skontrastowanymi. Zabiegiem niewerbalnym wspierającym pozytywne wartościowanie przedmiotu i świata, w którym ten przedmiot jest obecny, jest zastosowanie ruchu zwolnionego. Hieratyzuje i estetyzuje on przedmiot i świat z przedmiotem, nadaje im niezwykły charakter, umieszcza je w innym wymiarze - niedostępnym dla niewtajemniczonych, którzy nie dysponują tym przedmiotem.

W przekazach posługujących się perswazją niewerbalną - ale też szerzej: w każdym przekazie wieloznakowym - ruch, dźwięk, barwa są dla siebie wzajemnymi interpretatorami - czynnikami wzajemnie kształtującymi i wzmacniającymi swoje znaczenie i odbiór. W rozprawie poświęconej sztuce dźwięku Małgorzata Przedpełska-Bieniek pisze: „Jeśli dźwiękowi towarzyszy obraz, to zmienia się jego odbiór. Szczególny wpływ mają kolory. Pastelowe dają wrażenie dźwięku przydymionego, matowego, ostre i zdecydowane dźwięku silnego. Zależnie od głośności wydobywanego dźwięku i artykulacji, jaką zastosujemy, zmienia się jego barwa"18.

Dźwięk przekształca płaski obraz w przestrzeń trójwymiarową - nadaje mu głębię, uwiarygodnia. Muzyka sprawia, że przedmiot zostaje uduchowiony (poddany antropomorfizacji), ale i umieszczony w przestrzeni, która może stać się reprezentacją przestrzeni odbiorcy - realnej, bo trójwymiarowej, ale jednocześnie bardziej doskonałej, bo realizującej jego pragnienia i marzenia. Taką moc mają zarówno immanentne odgłosy codzienności, jak i transcendentna muzyka. Reklama jednak chętniej niż po te pierwsze sięga po tę ostatnią. Zastosowanie określonego, wspólnego dla całego przekazu tła muzycznego pozwala na wytworzenie w odbiorcy pożądanego dla danej reklamy stanu emocjonalnego. Muzyka sprawia, że w słuchaczu pobudzane są emocje, które ten następnie łatwo wiąże z tym, co towarzyszy muzyce - a więc z reklamowanym przedmiotem i jego światem (światem przedmiotu, przed mi o toświa te m - światem, który jest przedmiotem na

18 M. Przedpełska-Bieniek, Sztuka dźwięku. Technika i realizacja, Warszawa 2017, s. 44. 
sprzedaż; światem organizowanym, stworzonym przez przedmiot reklamy, nim uwarunkowanym).

Reasumując, perswazję niewerbalną w sztuce i reklamie różnią przyświecające im cele. Kompetencja perswazyjna, jaką dysponuje sztuka, jest dyspozycją wpisaną w formę artystyczną, ujawniającą się w jej zdolności do angażowania odbiorcy w grę toczącą się w ramach doświadczenia estetycznego. Jest to gra, która odsłania nieprzewidywalność formy artystycznej zdolnej do wzbudzenia w odbiorcy estetycznego zdziwienia, do zdemaskowania jego nawyków odbiorczych, wytrącenia go z kręgu bezpiecznych, ale nudnych przyzwyczajeń i przedsądów. Jako taka wpisuje się ona w istotę sztuki. Z kolei celem perswazji niewerbalnej w reklamie jest przede wszystkim zmiękczenie jawnej perswazji - przekształcenie jej w zapośredniczoną. Jest to perswazja, która sięga przede wszystkim po oddziaływanie zmysłowo-estetyczno-emocjonalne. Perswazja niewerbalna w powiązaniu z werbalną pozwala na angażowanie wielu zmysłów, na szybsze i bardziej skuteczne docieranie do odbiorcy. Pozwala na ekonomizację przekazu i wzmocnienie działania sterującego mającego na celu przekonanie odbiorcy do czegoś. Wpisuje się wreszcie w tendencje globalizacyjne i unifikacyjne charakterystyczne dla współczesnej światowej gospodarki i kultury.

\section{Bibliografia}

John Berger, Sposoby widzenia, tłum. M. Bryl, Aletheia, Warszawa 2008. J. Anthony Blair, The Rhetoric of Visual Arguments, [w:] Defining Visual Rhetorics, ed. Ch. A. Hill, M. Helmers, Routledge, New Jersey 2004.

Adam Dziadek, Relacja obraz - tekst. Próba charakterystyki typologicznej, [w:] Dwudziestowieczna ikonosfera w literaturach europejskich. Wizualizacja w literaturze, red. B. Tokarz, Śląsk, Katowice 2002.

Umberto Eco, Uwagi o ograniczeniach estetyki, tłum. P. Salwa, [w:] idem, Sztuka, Wydawnictwo M, Kraków 2008.

Philip Hamon, Ograniczenie dyskursu realistycznego, tłum. Z. Jamrozik, „Pamiętnik Literacki" 1983, z. 1.

Michel Foucault, Kim pan jest, profesorze Foucault? Debaty, rozmowy, polemiki, red. B. Błesznowski, K. M. Jaksender, K. Matuszewski, tłum. K. M. Jaksender, Znak, Kraków 2013. 
Tomasz Mann, Sztuka powieści. Wykład na uniwersytecie w Princeton, tłum.

M. Żurowski, [w:] idem, Eseje, wyb. D. Żmij-Zielińska, Muza, Warszawa 1998. Małgorzata Przedpełska-Bieniek, Sztuka dźwięku. Technika i realizacja, Wydawnictwo Wojciech Marzec, Warszawa 2017.

Mirosław Przylipiak, Kino stylu zerowego. Z zagadnień estetyki filmu fabularnego, GWP, Gdańsk 1994.

Byron Reeves, Clifford Nass, Media i ludzie, tłum. H. Szczerkowska, PIW, Warszawa 2000.

Paul Ricoeur, O sobie samym jako innym, tłum. B. Chełstowski, Wydawnictwo Naukowe PWN, Warszawa 2003.

Richard Rorty, Konsekwencje pragmatyzmu. Eseje $z$ lat 1972-1980, tłum. Cz. Karkowski, Wydawnictwo IFiS PAN, Warszawa 1998.

Michał Rusinek, Retoryka obrazu. Przyczynek do percepcyjnej teorii figur, Słowo/ Obraz Terytoria, Gdańsk 2012.

Ewa Szczęsna, Poetyka reklamy, Wydawnictwo Naukowe PWN, Warszawa 2001.

\section{Faces of Control. On Non-Verbal Persuasion in Art and Advertising}

The article deals with the issue of non-verbal persuasion in art and advertising. It shows and characterises the difference in the goals that both representations of non-verbal persuasion pursue. The author depicts the distinct way of textual existence of persuasion resulting from this discrepancy. The ontical contrast between persuasion in art and advertising is shown on specific examples of fine arts and audiovisual advertising.

Keywords: persuasion, art, advertising 